some interesting specimens were exhibited by Mr. Dairon, whose collection was also specially rich in Graptolites from the neighbourhood of Moffat. Mr. Dairon exhibited Liassic fossils from the Whitby district, and Mr. Bell illustrated the Liassic system of the Isle of Skye.

Mr. Wünsch, one of the vice-presidents of the Society, was as strong as any exhibitor of volcanic minerals collected by himself on Vesuvius and Etna, and in the volcanic district of the Auvergne Mountains. The same gentleman showed specimens of the fossilised remains of a primeval forest which he found in association with volcanic ash on the shores of the island of Arran a few years aro.

There is no public museum in Glasgow that is worthy of the name in which these collections could find a home. Overtures have been made, in at least one instance, to secure many of the specimens for museums or for private collections elsewhere. It will afford room for profound regret if the ultimate possession of such collections should be diverted from the west of Scotland, where they have almost entirely been collected. Surely the wealthy corlmasters, ironmasters, shipbuilders, man: facturers, merchants, and others in Glasgow and the surrounding district, are not so supremely devoted to money-getting that they cannot amongst them raise a fund of a few thousand pounds to found a museum, the geological position of which shall have as a nucleus those priceless collections already referred to. Possibly some definite shape may be given to this idea when, in the course of the next few years, the British Associat:on holds its third meeting in Glasgow, on which occasion the Glasgow geclogists will not fail to gratify the longings of their geological friends elsewhere, many of whom have but a faint idea of the intellectual feast which is in store for them.

JOHN MIAYER

\section{THE RISING OF AUSTRALIA}

$\mathrm{O}$

BSERVING that the gradual elevation of the land in the Australian portion of the southern hemisphere is attracting the attention of European geologists, I am induced to forward a few observations thereon, based upon personal investigation.

In March last, in a letter to the editor of this journal, under the title of "Circumpolar Land," Mr. Howorth cites a passage from my paper on the geological structure of this portion of the island, viz., Hobart Town. My remarks upon these post-pliocene evidences of terrestrial elevation were necessarily brief, owing to the various formations treated of in that contribution. I now therefore beg to draw the attention of the readers of NATURE to a few instances, in detail ; for the reason that I am satisfied the question is one that demands the strictest inquiry in the present stage of geological science.

Upon reading a paper before the Royal Society of Tasmania, in November 1864, on these shell deposits as evidence of recent upheaval of the coast, I found the majority of the observers there present regarded them as having originated at the hands of the aborigines; as being, in short, the refuse of their camps. But I then pointed out the fact that there were genera and species of testaceous remains far too small to have been taken by the blacks for the purpose of food. One argument at that time raised against my deductions was the fact that in some instances fragments of charcoal were found associated with the shells. Where this is the case (though the instances known to me are few) I think I shall be able to show that it is to be traced to subsequent drift agency, and has no connection whatever with the fcrmation of these shell beds.

One of the most interesting of these deposits is to be seen at Sandy Bay, an indent of the estuary of the river Derwent, distant from the city two miles. In a bank formed by a road-cutting distarit sixty yaris inland, and forty feet above high-water mark, exists a shell-bed three feet in thickness. The shells have a matrix of dark argillo-arenaceous soil, and beyond being more or less comminuted, $\epsilon$ specially the bivalves, exhibit few traces of geologic I age. Above the shell-bed repo: es a stratum of vegttable soil a few inches thick. The sh+lls rest upon a stratum of brown clay, having no traces of organisms; and that, in turn, reposes on coarsegrained yellow sandstone, 1raversed by veins of marl near its surface. The shells are all of genera and $s_{r}$ ecies now found living in the water only sixty yards in fiont of and below the deposit. They principally consist of Mytilus, Turbo, Trochus, Delphinulus, Vinus, Pcctcn, Ostrea, Patella, Cerethium, and Natica. In this bed a spcon-bowl-shaped fossil bone was found by a labourer employed in making the road, five years ago. A cast of the bone I recertiy forwarded to one of the first osteclogists of the age for identification. I have little doubt, however, that it is a bone of the hyoidal prociss of some Cetacean. It is 2 ? inches in length, by $22^{\mathrm{g}}$ in breadth, and presents no further signs of decay than the associated shells. At the distance of a mile from this spst seaward, there is another shell-deposit which has an average thicl:ness of two feet, re, osing on a basaltic overflow, and which again reposes on an arenaccous yellow clay, thickly perforated by Pholas. These beds are cxposcd in a vertical section of beiwecn thirly and forty feet in height.

Another locality where these evidinces of recent elevition of the coast are plainly secn, is in the Quecn's Domain, on the north eastern boundary of the ciry, and in the immediate vicinity of Gosernne: $t$ House. Hese, st ells are exposed in the surf $c$ ce scil, 500 yalds from the water-line of the estuary, but they are in a firely commir.uted condition. They are thickiy intersfersed through the bec's of the Royal Sociefy's Garders adjoining.

In the district of Lorre', which is fourtcen miles from the last-named locality in an easterly direction, there is a long low sandy llat, whose mean elevaticn above the sea-?evel I estimate at ten feet only. The arcnaceous soil of this plateau is thickly studded for about two square miles with oysier shells, come of them being much larger on the arerage than whit are taken x.ow. This platexu is separated from a cliff of sandstone by an arm of the sca about one mile wide and very shallow. The cliff is about eighty feet high and is known as the Bluff. On the top of this cliff is an extensive deposit of oyster shells corresponding in character to those in the flat below. Now, if a line were drawn from this bed of shells to the deposits referred to aiound Hobart 'Town, it would be fourd to occupy a mean altitude of these beds. The conclusion, I believe, to be arrived at from the fact of the same speci.s of sheils existing at such different levels above the sea as those on the cliff and those on the flat, is that the former are older than the latter, though both without coubt belong to the postpliocene epoch, and that the land has been gradually rising since the shells on the cliff contained their inhabitants up to the present time. That a silting up agency has been in operation with regard to the latter deposit is evident. The oyster shells are these kron'n as the mud oyster here, its habitat being mudbanks. Now they are found dispersed through an incoherent sandy deposit, derived from the erosion of the sandstone formations on the opposite shore. The counter-agency of such silting up is, however, infiritesimally small when compared to the scale on which the land is rising.

I might multiply these instances of recent elevation of the land, did time and space permit, by mentioning numerous other examples round the coast of this island. Leaving Tasmania, and going to the Australian mainland, we find their analogues there. While on a geolcgical visit to New South Wales and Victoria tro jears ago I was struck by the exact represertatiles of the se sta 
marks. In examining the shore of Hobson's Bay, Victoria, between Brighton and Mordiallac, I found recent shells in a ferruginous rock several feet above high-water mark, and exposed for more than a mile along the shore. This formation then gave place to a deposit of the same species of shells in a black sandy soil of the same character as those matrices mentioned as occurring here. I am thus able to add my humble testimony to the truth of the statements made by those geologists mentioned by Mr. Howorth. Not only do Tasmanian post-pliocene marine deposits find their analogues in New South Wales, Victoria, and other parts of the Australian mainland, but also the Miocene territory formations have their representatives there. For instance; at the East coast of this island seventy miles distant from Hobart Town, exist some very fine Miocene shell beds reposing on Silurian strata. These beds have their analogues in Victoria, at Schnapper point, where they also repose on Silurian strata. Again the somewhat celebrated Travertin deposit on the eastern bank of the Derwent, mentioned by Mr. Darvin, is completely represented at Geelong in that colony. I mention these last somewhat irrelevant features to show the analogy of physical conditions which existed in distant parts of Australasia from the middle Tertiary epoch down to the post-pliocene.

The oscillation of the land towards the Polar Regions is a question that demands strict and patient inquiry. That such a mutation is going on in this part of the globe, every intelligent geological observer is conscious of, and that at a computed rate of ten feet in the century. This is a fact which involves a variety of considerations with respect to past geological operations, and the popular theories propounded to explain them.

Although the land in this part of the globe is rapidly rising as well as according to published observations, that, in the Arctic regions, still $\mathrm{I}$ am in a position to show that an opposite movement took place during the close of the Tertiary or the dawn of the Pleistocene epochs by a sinking of certain tracts of land whereby Tasmania and New Zealand were isolated from the Australian mainland. I cannot do more at the present time than allude en passant to the important fact, and which must form the subject of a future communication.

Since writing the above I have examined a raised beach in the district of Sorrel, of many hundreds of acres in extent, composed of shells, having a mean thickness of five feet. The deposit is overgrown with trees and scrub. The trees are chiefly the Casuarina, or she-oak of the colonists, and it evidently flourishes on a soil of little else than shells. Although years ago lime burning was carried on for some years, so enormous is the deposit that there is scarcely a perceptible diminution.

Hobart Town, Oct. I

S. H. WINTLE

\section{THE COLOURED STARS ABOUT KAPPA CRUCIS}

M R. H. C. RUSSELL, of the Sydney Observatory, $\mathrm{NI}$ sends us an account of some observations he has recently made on the above small but beautiful cluster of stars. He believes his researches probably point it out as one of the stations from which astronomers will gatn fresh knowledge of the starry heavens. He gives a history of the cluster from its first recorded observation by Lacaille in 1750 . Dunlop, about 1828 , puts two stars in the place now occupied by $\phi$, which has considerably altered its place since Herschel made his map in 1835 . The star No. 87, Dunlop does not represent at, all, and says nothing of colour, though fond of recording coloured stars. In 1835 Herschel wrote a monograph on Kappa Crucis, and placed all the stars (I IO) on his map, but saw no nebulous light. Abbott of Tasmania, in r862, laid down 75 stars, and noted colours, remarking that certain changes were apparently taking place in the number, position, and colour of the component stars of the cluster. Nothing has been done since Abbott, till Mr. Russell determined to test for himself the latter's statement. He made a catalogue of all the stars (I30) seen with the Sydney equatorial, a coloured map showing all the stars, and notes. His map takes in as much space as Herschel's, but is four times as large. A close inspection shows a great many changes since Herschel observed, of which the most conspicuous of all is in the change between the present and past position of three stars, Nos. II, 2r, and 28, which have all moved from 4 to 6 seconds; and the star $\phi$ has also moved half a second in an opposite direction, and come nearly, but not quite, in a straight line with $\delta$ and $\epsilon$, which line, if produced, passes, not through $\zeta$, as in Abbott's observations, but half way between $\gamma$ and $\zeta$ Considerable change has also taken place in Nos. 1oo, I06, I20, 122, I26, and some others; and it is remarkable that the changes in the south preceding line are nearly all in R. A., while in those near $\beta$ and in the following side they are in declination, as if the cluster were made up of three sets of stars, two of which drift from the third in different directions. Five of Herschel's stars he could not see, but found 25 Herschel did not see; stars which, though all small, are yet in most cases brighter than some of those which Herschel recognised, and if there when Herschel examined, the cluster would not have been omitted; they are all well within the limits of his map, and several in parts of it which must have been most carefully examined. Two of them are near $a$, one near the string of stars south following it, one between $\beta$ and $\delta$, and two in the triangle 50s. after $a$, where Herschel shows 3 stars; of the others 5 precede $\alpha$ from is to $25 \mathrm{~s}$, 5 follow it from I 5 to $25 \mathrm{~s}$. and on the south side; 8 are on the north following side, and $\mathrm{I}$ cn the south following. Their numbers in my list are $2,3,4,6,7,15,19,31,60,69,73$, $76,79,86$, I10, I16, I17, I20, 123, 124, 125, 127, I28, I 29 , and I30. In Mr. Russell's list there are 24 stars about the roth magnitude, while in Herschel's there are only 7 ; and the mean magnitude of Herschel's 130 is 13 , while the mean of Russell's I 30 is I2.

These facts prove beyond all question, Mr. Russell thinks, that from some cause there has, as in the nebula of $\eta$ Argus, been here a considerable increase in brilliancy.

Mr. Russell thinks that we must either give up analogy, our safest guide, in such reasoning, or admit the gradual extinction of light in its passage through space, with its millions of meteor streams cutting the ecliptic at all angles, its thousands of comets, its meteoric dust, its zodiacal light, its solar corona, its material atmosphere, so to speak, occupying not only all the interplanetary space, but more or less to the limit of the sun's attractive force.

"And if we are to take our sun as a type of other suns, and in the mind's eye see all surrounded by such an atmosphere, and people all the interspaces with myriads of myriads of comets-nay more, if we accept the view held to be most probable by many astronomers, that it is by the deposition of this material atmosphere on the sun and planets that they are hourly growing and finding those stores of light and heat by which all things live, it is beyond question that there must have been a time when this material atmosphere was far more dense than it is at the present moment, and that there must be in every direction other suns in all stages of the process from the great nebulosity ' without form and void', to the Finished Sun, whatever that may be ; or, in other words, amidst the infinitude of such systems with which we are surrounded, there are places.where probably a sensible amount of clearing up has taken place within the last 35 years.

"And I think in this view we find a rational explanation of the appearance of new stars in this cluster, more especially since it has been shown by others, as well as 